\title{
New paradigms of pneumatological ecclesiology brought about by new prophetic churches within South African Pentecostalism
}

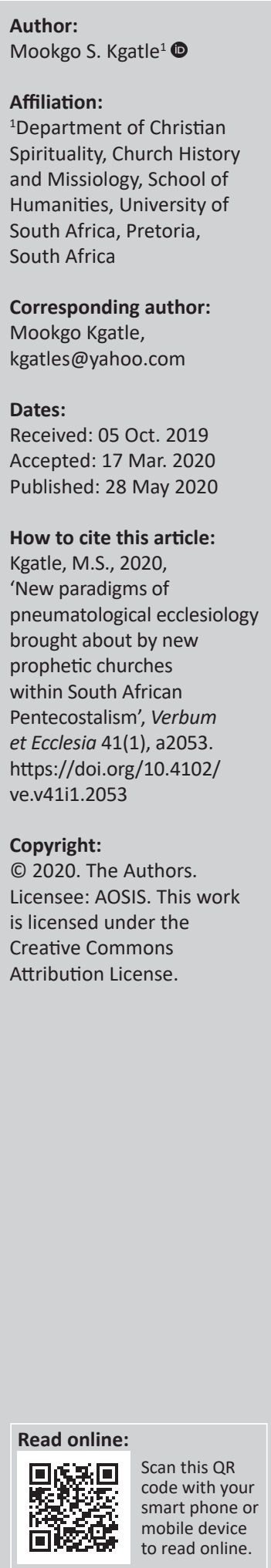

Pneumatological ecclesiology has caught the interest of many Pentecostal theologians, especially in the three main sub-traditions of Pentecostalism, that is, classical Pentecostalism (later CP), Pentecostal African Independent Churches (later PAIC) and charismatics. There is however a research gap in studying pneumatological ecclesiology in the new prophetic churches (later NPCs). Therefore, the study of pneumatological ecclesiology in light of the NPCs in South Africa is pivotal, groundbreaking and cutting-edge. The challenge of course to such a study is the existence of many ecclesiologies within the sub-traditions of Pentecostalism stated above. To avoid this challenge, a summary of pneumatological ecclesiology in other sub-traditions shall be given but with a special focus on new paradigms in NPCs. The argument is that the pneumatological ecclesiology amongst NPCs in South Africa is very much different in praxis from the ecclesiology of the three main sub-traditions of Pentecostalism. The aim of this article was to demonstrate the existence of the lived ecclesiology, highlight the challenges and propose a balanced pneumatological ecclesiology amongst NPCs in South Africa.

Intradisciplinary and/or interdisciplinary implications: This article is an interdisciplinary study between missiology and practical theology. It studies the practical theological theme of ecclesiology within the streams of a missiological trend of Pentecostalism in order to highlight the new paradigms of pneumatological ecclesiology.

Keywords: classical Pentecostalism; new prophetic churches; ecclessiology; African-initiated churches; pneumatology.

\section{Introduction}

Ecclesiology is the study of church behaviour in relation to the way a specific church views issues of importance like salvation, the work of Christ, doctrine and others. Pneumatological ecclesiology is more contextual and experiential as opposed to ecclesiology of other denominations or orientations. Pentecostals never envisaged to theorise their ecclesiology or the way the church needs to conduct herself with regard to theology. They were more focussed on the experiential ecclesiology than a theoretical one. They were inspired by the early church of the Apostles, which was full of life (Kärkkäinen 2001:102). Pneumatological ecclesiology is concerned with the fundamental teachings of Pentecostalism like Spirit baptism and less concerned about theoretical underpinnings (Clifton 2007:217). Therefore, in order to understand a pneumatological ecclesiology, one needs to look at their experiences and spirituality and not necessarily at their theology. The spiritual experiences in Pentecostalism are a common denominator amongst all the streams of Pentecostalism. It is also a factor that brings together all the divergent views within Pentecostalism (Cartledge 2014:14). Pneumatological ecclesiology is influential and aims at going out to the world and ministering the gospel to other nations. The believers carrying this influence are expected to influence others in serving God and his kingdom (Pinnock 2006:151).

The study of pneumatological ecclesiology poses a challenge: Does a uniform pneumatological ecclesiology exist? Given the different streams and diversity of Pentecostalism, we should speak about pneumatological ecclesiologies, and scholars agree with this view because an endeavour to study one form of ecclesiology in Pentecostalism cannot satisfy all streams (Lord 2012:27). The study of pneumatological ecclesiology should be focussed on a specific denomination or congregation to avoid generalisations. For pneumatological ecclesiology scholars to succeed in their study, they should define and zoom onto the trajectory or stream of their particular interest (Clifton 2007:217). However, for this study, because the goal is to illustrate that the pneumatological 
ecclesiology of new prophetic churches (NPCs) is different, one is forced to summarily look at pneumatological ecclesiology in all the streams of Pentecostalism: classical Pentecostalism (CP), Pentecostal-type African Independent Churches (PAIC) and Charismatics. This will be done to establish how these streams are different to the study of pneumatological ecclesiology in NPCs.

\section{Definition of pneumatological ecclesiology}

The scholar who introduced a pneumatological ecclesiology in his book, Toward a pneumatological theology: Pentecostal and ecumenical perspectives on ecclesiology, soteriology, and theology of mission, is Kärkkäinen (2002). A pneumatological ecclesiology draws a relationship between the behaviour of the church and the Spirit, which is very much common in Pentecostalism. In Pentecostalism, according to Kärkkäinen, there is no separation between the work of Christ, the church and the Spirit (2002:83). Given this mutually inclusive relationship between Christ, the church and the Spirit, the conclusion is that the Spirit is the one that joins both Christ and the church. Hence, instead of speaking about a Christological ecclesiology, for example, Kärkkäinen speaks about a pneumatological one (2002:93). The role of the Spirit is pivotal in making the church to be jovial instead of being a cold one. Thus, the church depends on the Spirit in order to exuberate the elements of enthusiasm. By enthusiasm here one refers to the active role that the Spirit plays in igniting the passion in the church (2002:93). Thus, pneumatology according to Kärkkäinen is not adding to the functionality of the church but is the main function of the church in Pentecostalism. It is the engine that keeps the church going. This makes pneumatology in Pentecostalism the centre of ecclesiology (2009:100).

Therefore, according to the Pentecostals, the Spirit is the revelation where Christ builds the church; hence, the Spirit is important to study ecclesiology. In addition, the Spirit is the force that brings unity amongst believers, which in turn brings the fellowship of believers. However, the contribution of an individual is equally important to that fellowship. Therefore, even if we were to speak of an ecclesiology in general terms, in Pentecostalism, it will still be driven by the Spirit. The Spirit is responsible for bringing the believers together. People who have been introduced to Christ need the Spirit to learn and practice whatever Christ taught the church whilst he was still on earth. Whilst Christ established his church in doctrine, it is the work of the Spirit to ensure that whatever Christ has established lives in the hearts of the believers (Coulter 2007:68). Therefore, Pentecostals are inclined more towards the work of the Spirit and believe that the Spirit has been assigned by Jesus who came from the Father to work and function in the life of the believer. Pentecostals believe in the person of the Holy Spirit as the one who enables the believer to reject sin and manifest the glory of God whilst on earth. Thus, the Holy Spirit is pivotal in studying how the believers and the whole church functions in Pentecostalism; hence, in this paper, the researcher speaks of a pneumatological ecclesiology.

\section{Pneumatological ecclesiology in classical Pentecostalism}

By CP in South Africa, one refers to churches that believe in the baptism of the Holy Spirit and looks to the revivals around the beginning of the 20th century for their origins. The churches include the Apostolic Faith Mission of South Africa, Full Gospel, the Assemblies of God and several others. Since the beginning, these Pentecostal churches in South Africa believed in the dynamic work of the Holy Spirit in terms of ecclesiology. They embraced salvation, sanctification and the second coming of the Lord Jesus Christ in the light of the work of the Holy Spirit. Thus, the church has always been interpreted in terms of the revelation of the Holy Spirit (Gause 2006:185). Some of the CP believes in the baptism of the Holy Spirit with the initial evidence of speaking in other tongues, as it happened in the Book of Acts. In addition to speaking in tongues, the expectation is that their members should have a good character and bear fruit of love, joy, peace, patience, kindness, goodness, faithfulness, gentleness and self-control. They are expected to live an exemplary life even outside the church premises to model good characteristics even when amongst unbelievers. Thus, the baptism in the Holy Spirit and the speaking in tongues are not the only measuring yardsticks in authenticating the behaviour of the believer. The believer is also expected to demonstrate a level of character instead of only relying on the charisma that comes as a result of being baptised in the Holy Spirit.

Classical Pentecostalism accommodates other movements like the evangelical, holiness, revivalist and so forth. In fact, it is more correct to say that $\mathrm{CP}$ was built from such movements. Classical Pentecostalism grew from those movements and included the issue of the baptism of the Holy Spirit with the evidence of speaking in other tongues. They did not do away with the traditions within these other movements. Thus, they still believe in holiness, salvation, divine healing and the return of the Lord Jesus Christ. What is fundamental in CP is the belief in the Holy Spirit and the fellowship and participation of all believers and, in many instances, the inclusion of women in the preaching of the gospel. The work of the Holy Spirit is showing people their sin and leading them to salvation is pivotal in $\mathrm{CP}$. Classical Pentecostalism believes that the same Holy Spirit is active in the believer even post conversion and therefore instrumental in the growth of an individual believer. According to Brunner, $\mathrm{CP}$ envisages to be different from evangelicals in terms of the fundamental teachings of Pentecostalism. What they care about is to maintain the work of the Spirit as a supernatural work that happened as a result of Spirit baptism. This work should enable the believer to go through daily challenges and overcome them. This is exactly what transpired in the early church - believers were baptised in the Holy Spirit and therefore were able to do supernatural works (Brunner 1997:36). 


\section{Pneumatological ecclesiology in Pentecostal-type African-initiated churches}

There are different categorisations of African Independent Churches (AICs) like Zionist type, Ethiopian, Pentecostal type and others. Whilst churches like Zion Christian Church (ZCC), International Pentecostal Holiness Church (IPHC) can be categorised as Zionist, churches like St John Apostolic Faith Mission can be categorised as the PAICs. Most recently, there are churches like Rivers of Living Waters (RLW) of Bishop Stephen Zondo and Tirano of Apostle Simon Mokoena, which can also be categorised under PAICs. The main difference between CP and PAICs is their operations, especially in terms of liturgy and ministrations. Pentecostaltype AICs have a more Africanised liturgy in terms of the style of worship, and the preachers most of the time preach in indigenous languages. The PAICs are found in townships where there are challenges like poverty, unemployment and inequalities. They are churches seeking to minister to these needs of the people. The key thing in PAICs is divine healing, which in this instance is demonstrated through song and worship. The PAICs are rooted in the word, in the belief of the triune God, God-the father, God-the son and God-the Holy Spirit. They believe in the baptism of the Holy Spirit with the evidence of speaking in other tongues. In essence, they are not much different from the classical Pentecostal churches.

In the PAICs, African people are used to the role and work of the Holy Spirit in worship, and they can relate it to their own daily living as many were already introduced to the spirit world in African traditional religions. In addition, culture and traditions have been fused into the work of the Holy Spirit in the ecclesiology of PAICs. On a positive note, this kind of ecclesiology is able to bring transformation to the Western ecclesiologies that are already operating in an African space. Preaching in the PAICs is done with the combination of symbols and other proverbs within African culture and traditions. The prophets in the PAICs are perceived as those who speak on behalf of God in order to address the social ills that the people are going through in their lives. This kind of ecclesiology is not necessarily opposed to Christian faith but practices? Faith relevantly in an African context (Mwambazambi 2011:8). An important role of bringing people together and ministering healing to their wounds. Thus, pneumatological ecclesiology in PAICs represents the African people in terms of practice, and what remains a question is the development of the theology of ecclesiology in the context of PAICs.

\section{Pneumatological ecclesiology amongst charismatics}

Charismatics are churches that have retained their Pentecostal roots but became independent from CP. The word independent is used here because many of these churches have no association with foreign main denominations such as the North American Pentecostal denominations. However, it must be noted that the practice of faith amongst charismatics is influenced by the Word of Faith Movement of Kenneth Hagin, Kenneth Copeland and Creflo Dollar. Hence, there is a consistent teaching on the word of faith that speaks about prosperity message where believers are encouraged to prosper in all areas of their lives. In South Africa, these are churches like the Grace Bible Church founded by Bishop Mosa Sono in Soweto, Kingdom Life Church founded by Dr Muligwe in Venda. The most successful charismatic church is the Rhema Bible Church founded by Ray McCauley in Randburg. The above are just a few examples, as there are so many charismatics in South Africa spread across the nine provinces of the country.

In the context of pneumatological ecclesiology, charismatics are known for emphasising the gift of the Holy Spirit in 1 Corinthians 12 like the spirit of wisdom, word of knowledge, faith, the gift of healing, the working of miracles, prophecy, discerning of spirits, diverse kinds of tongues and the interpretation of tongues (1 Cor 12). Charismatics are not much in the fivefold ministry, as they do not mind calling everybody a pastor. They maintain the order that is found in $\mathrm{CP}$, as they also believe in the baptism of the Holy Spirit with the evidence of speaking in other tongues but not as initial signs as CP does. Another distinction is the belief in the participation of all believers in terms of utilising their gifts to empower the body of Christ. Thus, amongst charismatics, believers are taught to know their gifts and use such gifts in the church and elsewhere in the marketplace. It must be emphasised that the pastor or the leader of a congregation is not perceived as the sole gifted person in the church because they emphasise that the Holy Spirit dwells in every believer.

\section{The new prophetic churches in South Africa}

The NPCs are churches that have retained the fundamental teachings of Pentecostalism like the baptism in the Holy Spirit and speaking in tongues but have peculiar practices like one-on-one prophecy, one-on-one deliverance and consultations, where members pay a certain fee (Tsekpoe 2019:284), miracle money, prophetic titles, with some prophets claiming superiority over biblical prophets (Banda 2020:1) and others. Prophecy is the most significant feature of these churches and has been the source of growth amongst the NPCs in South Africa. Even pastors who initially did not prophesy begin to engage in one-on-one prophetic ministry when they align to these types of churches. These are churches like the Enlightened Christian Gathering (ECG) of Prophet Shepherd Bushiri in Pretoria. Bushiri is not only the founder of ECG but also a business owner and investor (Dube 2020:42; cf. Ramantswana 2019:4). Others are the Alleluia Ministry of Pastor Alph Lukau in Randburg, Rabboni Ministries in Soshanguve, Incredible Happenings of Pastor Paseka Motsoeneng and many others. What is more peculiar about the NPCs in South Africa is that in the years between 2014 and 2019, some pastors encouraged their members to 
engage in outrageous acts like the eating of snakes, eating of dog-meat, drinking of petrol, taking selfies in heaven, spraying of doom, walking on air, body walking, bodyresurrecting, money laundering and others.

In the context of pneumatological ecclesiology, most of the churches in the NPCs do not focus on the baptism of the Holy Spirit with the initial evidence of speaking in tongues. The pastors do speak in other tongues on the pulpit but do not emphasise it to the believers that they are obliged to speak in other tongues. New prophetic churches instead of talking about Spirit baptism, would rather speak about the demonstration of the power of the Holy Spirit amongst believers. There also seems to be a corporate participation of all believers in their services whereby both the young people and the women do take part in the liturgy. Most importantly, people of all ages and gender do take part in the leadership positions of the church. The NPCs are not very much focussed on holiness or the sanctification of the believer such that believers can live a different lifestyle but can still participate in church. Therefore, the preaching of NPCs is more focussed on the prosperity, healing, deliverance and the prophecy of the believer.

\section{New prophetic churches as new paradigms of pneumatological ecclesiology}

The NPCs in this article serve as new paradigms of pneumatological ecclesiology because they are different in approach to other three sub-traditions of Pentecostalism. The most significant difference when compared with CP lies in the fact that the emphasis in the NPCs is not the initial evidence, and members do not have to speak in tongues for them to participate in the leadership or positions of the church. Although most members in the NPCs in South Africa do speak in tongues, the speaking in tongues does not form the central message. They may speak in tongues but may relegate this activity to times of personal devotion or small group meetings. In addition, the lifestyle of an individual does not serve as motivation for them to participate in the church. In contrast to $\mathrm{CP}$, people are not watched as to how they live their lives in order to deter them from serving in the church. The lifestyle of individuals is left to them to decide as to how they carry themselves. Leadership positions in the church are given with the hope that the individual will do well. Hence, such leadership positions are given even to young people, which is something that other streams do not do at times. CPs grant leadership based on age and experience, whereas NPCs grant leadership position based on ability and charisma.

The other difference between the CP and NPCs is that, the latter includes other operations like the demonstrations of power in their liturgy. In the NPCs, the reception of power is combined with the demonstration of it to others. There is demonstration of the power of the Holy Spirit in healing, prophecies and other miracles. In the NPCs, the work of the
Holy Spirit does not only end in the baptism in the Holy Spirit and speaking in tongues, it goes deeper and heals people, delivers others and reveals the word to others in the form of consultations. The extension of the work of the Holy Spirit has made people move from CP to NPCs because they want to see what they are missing. In NPCs, the people are meant to seek more from the presence of the Holy Spirit than just to speak in other tongues. Thus, the speaking in tongues is not emphasised over and above other works of the Holy Spirit.

In their preaching, the NPCs preachers instead of focussing on preaching a confrontational gospel that focusses on repentance, holiness, sanctification, focus on healing, deliverance, prosperity and other miracles. New prophetic churches preach salvation that is more focussed on material accumulation connected to prosperity gospel. One seldom hears a preacher in this age talking about salvation; they would rather talk about the blessings than to preach salvation. Instead of preaching heaven and the requirements to go there, they would rather speak about 'heaven on earth' or what is known as realised eschatology, which is another main point of difference. New prophetic churches focus much on the here and the now than a future eschatology. This is also demonstrated by the lifestyles of the pastors in terms of the cars they drive and the houses they live in - these are all illustrations of their sermons. To sum up, the focus in NPCs is on the pastor rather than on Jesus. In CP, the focus is still on Jesus than personalities.

In contrast to the PAICs, the NPCs preachers sermonise in English. It is correct that they use a more sophisticated language that is not familiar in the townships. They speak a language that sits well with high-market people and the elite. The worship team in the NPCs do not sing African songs that are normally sung in any of the indigenous languages. However, they sing in English and they ape the style of many Western worship teams like Hillsong in Australia in presenting their liturgy. Hence, they are multiracial, which is very important in racially divided South Africa. Thus, they cannot be likened to PAICs that are too local and make sure that their message accommodates an average person in their community or locality. Some of the prophets in the NPCs are not humble enough to understand the challenges of their followers. African leaders start the NPCs but do not take the form of PAICs. They are located in Africa and relevant to African people but do not necessarily take African cultures and tradition into consideration - they are more modernised. They are more into modern technology and media than the PAICs.

The NPCs are different to charismatics; although many of their leaders are very gifted, articulate and presentable, the level of order in using their gifts is very much different from that of charismatics. In the NPCs, the gifted person is glorified more than the giver of that gift. In the charismatics, the Holy Spirit is acknowledged as the one who apportions gifts to the believers. Thus, the charismatics believe that everyone is 
gifted and should allow God to use them and their gifts, and they should excel in using such gifts. It is not so in the NPCs; the leader is the one who is more gifted than the rest of the members, and they all must hear from him or her. The other difference is that NPCs take the power of amulets and fetishes with utter seriousness - and consequently reject them - but also provide alternatives in the forms of anointing oil, blessed water, calendars or handkerchiefs.

\section{Lived ecclesiology}

The NPCs, according to Miller and Yamamori, are practicing a lived ecclesiology in the sense that they do not only believe in the baptism of the Holy Spit but also make sure that the way they present their message is well received by the young people. At the end, even the affluent people end up joining their services because they appeal to them (Miller \& Yamamori 2007:27). This is seen mainly in the way they conduct their worship service, as it is full of life, jovial and enthusiastic. They do not only concentrate on the spirituality of their music but also ensure that they sing modern and popular songs in their services. The loud and popular music appeal to the young generation because they are already used to such sounds in the secular world. In addition, such music is presented with audio-visuals, whereby if people who do not understand or know the song can easily read it on the projector (De Witte 2008:54). Some of these factors do feature in other streams of Pentecostalism, but because of rigidity they cannot be as visible as in the NPCs. Therefore, the NPCs are at the forefront of the gospel music that is alive and full of new rhythms in worship (Thompson 2015:12).

The preachers of NPCs are very good in terms of presenting the gospel with the combination of modern technology. Pentecostal preaching in the NPCs is more than a sermon presentation; it takes the form of a new technology presentation, which happens in motivational talks and secular gatherings (White 2016:47). The use of technology has become the main concentration amongst NPCs in the sense that whatever happens in their church service, they make sure that they put it in their media platforms like Facebook, Twitter and YouTube. Hence, advertising in NPCs play a major role in terms of the growth of these types of churches. They ensure that healing, deliverance and other acts are advertised on those platforms (Khanyile 2016:90). The use of technology in sermon presentation has changed the way pastors present their gospel, often resulting in a change in the way people perceive church service. Instead of being bored and waiting for the pastors to finish their sermon, the members are actively involved in the presentation of the sermon (Magezi 2015:5). Thus, instead of just relying on the Holy Spirit, the NPCs have adopted a business model of presentation by the use of modern technology. Worship is no longer defined in terms of singing, clapping and preaching; it is now combined with new technology that appeals to the young generation (Togarasei 2012:258).

\section{Some challenges}

The challenge with a Pentecostal pneumatological ecclesiology amongst the NPCs is that the followers in these churches do not perceive the Bible as the centre of the spiritual experiences in church (Mashau 2013:12). Another challenge, especially in recent times, is that the believers were encouraged to engage in outrageous acts like eating of snakes, drinking of petrol and other acts. Although, it is a good thing to be instructed by the Holy Spirit, the challenge is when people do wrong things and claim to have been led by the Spirit when they engaged in such acts. Most pastors who led people to eat grass, drink petrol, eat snake, walk on air, resurrect dead bodies and so forth have all said that the 'Spirit' had instructed them to do so. Some pastors will even be bold enough to tell a young girl or any woman that the 'Spirit' of God has instructed them to sleep with them. This means that when young girls and women visit the pastors' rooms for counselling, some of them do not receive any such counselling but end being forced by some of their pastors to sleep with them. What one seeks to highlight here is that when the pastor says he is led by the Spirit, it positions the victim in a corner because they equally believe in the same Spirit.

\section{Towards a balanced African pneumatological ecclesiology}

Whilst it is important for a pneumatological ecclesiology in Africa to consider social and cultural factors in the continent, it should be done without compromising ethical issues. Therefore, a balanced African pneumatological ecclesiology should be an ethical one. The relationship between ecclesiology and ethics is important in order to deal with the churches that abuse the people of God in the name of the Spirit. The ethical implications mean that people will not be encouraged to engage in such acts. This relationship will also play a big role in ensuring that African cultural values are not overlooked in religious spaces because the church leaders seem to be inclined towards the Spirit (Sakupapa 2018:1). A balanced African pneumatological ecclesiology needs to place God before the human leaders who can go wrong at any time (Mwambazambi 2011:8). In addition, although many of them do not use the Bible as their main text, it should be an ecclesiology that values the biblical truth. This will allow the society to view the experiences in the church and be able to judge them through biblical lenses. It will afford the church an opportunity to have a well-grounded doctrine in terms of what they believe and practice in their services. When there is deviation from such a doctrine, there will be an opportunity for repentance and correction.

\section{Conclusion}

It can be concluded that ecclesiology in all the main three sub-traditions of Pentecostalism, that is, CP, PAICs and charismatics is pneumatological one given the inclination to the Holy Spirit by Pentecostals. Thus, instead of speaking of a general ecclesiology, we should speak of a pneumatological ecclesiology. The study on pneumatological ecclesiology in all 
the three well-recognised streams of Pentecostalism demonstrates that there are new paradigms of ecclesiology brought about by NPCs. The NPCs do not focus on the initial evidence of speaking in tongues although they recognise the baptism in the Holy Spirit. They do not prioritise the fruit of the Holy Spirit, especially when choosing people for major positions in the church. They use new technology in the presentation of their sermons. New prophetic churches do not recognise the gifts of all believers but focus on the gift of the leader, many of whom bear the title of a 'prophet'. They dwell more in the manifestation and demonstrations of the Holy Spirit in healing, deliverance and prosperity. Although these new churches have a lived ecclesiology, the challenge is the misuse of the Spirit. This challenge can be overcome by having an ecclesiology that is ethical, based on the bible and still embraces African culture.

\section{Acknowledgements}

The author would like to thank the Department of Christian Spirituality, Church History and Missiology for the support provided in conducting this research.

\section{Competing interests}

The author has declared that no competing interests exist.

\section{Authors' contributions}

This article is solely written by M.S.K.

\section{Ethical considerations}

Ethical clearance was obtained from the University of South Africa, College of Human Sciences Research Ethics Review Committee (reference number: 2019-CHS-90343018-Dept).

\section{Funding information}

This study was financially supported by the University of South Africa.

\section{Data availability statement}

Data sharing is not applicable to this article as no new data were created or analysed in this study.

\section{Disclaimer}

The views and opinions expressed in this article are those of the author and do not necessarily reflect the official policy or position of any affiliated agency of the author.

\section{References}

Banda, C., 2020, 'Mediating God's relationality? A trinitarian perichoretic critique of the reliance on anointed objects in African neo-Pentecostalism', HTS Teologiese Studies/Theological Studies 76(1), a5856. https://doi.org/10.4102/ hts.v76i1.5856

Brunner, F.D., 1997, A theology of the Holy Spirit: The Pentecostal experience and the New Testament witness, Wipf and Stock Publishers, Eugene, OR.

Cartledge, M.J., 2014, 'Renewal ecclesiology in empirical perspective', Pneuma 36(1), 5-24. https://doi.org/10.1163/15700747-13360101

Clifton, S., 2007, 'Pentecostal ecclesiology: A methodological proposal for a diverse movement', Journal of Pentecostal Theology 15(2), 213-232. https://doi. org/10.1177/0966736907076339

Coulter, D., 2007, 'The development of ecclesiology in the Church of God (Cleveland, TN): A forgotten contribution?', Pneuma 29(1), 59-85. https://doi.org/10. 1163/157007407X178247

De Witte, M., 2008, 'Accra's sounds and sacred spaces', International Journal of Urban and Regional Research 32(3), 690-709. https://doi.org/10.1111/j.14682427.2008.00805.x

Dube, B., 2020, "'Go and prophesy in your own land": Foreign prophets and popularism in South Africa. Evoking the need of Jonathanic theology for peaceful resolution of difference', Religions 11(1), 42. https://doi.org/10.3390/ rel11010042

Gause, R., 2006, 'A Pentecostal response to Pinnock's proposal', Journal of Pentecostal Theology 14(2), 183-188. https://doi.org/10.1177/0966736906062131

Kärkkäinen, V.M., 2001, 'Church as Charismatic fellowship: Ecclesiological reflections from the Pentecostal-Roman Catholic dialogue', Journal of Pentecostal Theology 9(1), 100-121. https://doi.org/10.1163/17455251-00901006

Kärkkäinen, V.M., 2002, Toward a pneumatological theology: Pentecostal and ecumenical perspectives on ecclesiology, soteriology, and theology of mission, University Press of America, Lanham, MD.

Kärkkäinen, V.M., 2009, An introduction to ecclesiology: Ecumenical, historical \& global perspectives, InterVarsity Press, Westmont, IL.

Khanyile, S.B., 2016, 'The virtualization of the Church: New media representations of neo-Pentecostal', Doctoral dissertation, University of the Witwatersrand, Johannesburg

Lord, A., 2012, Network church: A Pentecostal ecclesiology shaped by mission, Brill, Leiden.

Magezi, V., 2015, 'Technologically changing African context and usage of information communication and technology in churches: Towards discerning emerging identities in church practice (a case study of two Zimbabwean cities)', HTS Teologiese Studies/Theological Studies 71(2), 1-8. https://doi.org/10.4102/hts. v71i2.2625

Mashau, T.D., 2013, 'Ministering effectively in the context of Pentecostalism in Africa: A reformed missional reflection', In die Skriflig 47(1), 10-17. https://doi. org/10.4102/ids.v47i1.84

Miller, D.E. \& Yamamori, T., 2007, Global Pentecostalism: The new face of Christian social engagement, University of California Press, CA.

Mwambazambi, K., 2011, 'A missiological reflection on African ecclesiology', Verbum et Ecclesia 32(1), 1-8. https://doi.org/10.4102/ve.v32i1.482

Pinnock, C., 2006, 'Church in the power of the Holy Spirit: The promise of Pentecostal ecclesiology', Journal of Pentecostal Theology 14(2), 147-165. https://doi. org/10.1177/0966736906062119

Ramantswana, H., 2019, 'Prophets praying for, or preying on people's faith: A reflection on prophetic ministry in the South African context', In die Skriflig/In Luce Verbi 53(4), 8. https://doi.org/10.4102/ids.v53i4.2495

Sakupapa, T.C., 2018, 'Ecumenical ecclesiology in the African context: Towards a view of the church as Ubuntu', Scriptura 117, 1-15. https://doi.org/10.7833/117-11384

Thompson, R.L., 2015, The production of gospel music: An ethnographic study of studio-recorded music in Bellville, University of the Western Cape, Cape Town.

Togarasei, L., 2012, 'Mediating the gospel: Pentecostal Christianity and media technology in Botswana and Zimbabwe', Journal of Contemporary Religion 27(2), 257-274. https://doi.org/10.1080/13537903.2012.675740

Tsekpoe, C., 2019, 'Contemporary prophetic and deliverance ministry challenges in Africa', Transformation 36(4), 280-291. https://doi.org/10.1177/0265378819 866217

White, A.G., 2016, 'Pentecostal preaching as a modern epistle: A comparison of Pentecostal preaching with Paul's practice of letter writing' Journal of Pentecostal Theology 25(1), 123-149. https://doi.org/10.1163/17455251-02501013 